\title{
Impact of Blind Thoughts on Higher Education: A Case Study
}

\author{
Dr. Sudipta Chakraborty, \\ Department of Education, The Sibsagar College, Joysagar, Assam, India.
}

\begin{abstract}
Superstition is the fear of what is unknown and mysterious. It is the belief that certain events bring good or bad luck which cannot be explained by reason or science. In short, superstition means blind belief. Superstition is a worldwide phenomenon. People in every country believe in one or the other superstition. In this paper, an attempt has been made to analyze the false beliefs existing among the students of Scheduled Caste Community studying in higher educational institutions of Dibrugarh Town. Moreover, the researcher wanted to study the false beliefs existing among the parents of these students studying in the higher educational institutions of Dibrugarh Town.

This study is based on primary data collection. The total sample collected is 120 students studying in higher educational institutions and their parents through incidental sampling technique.

A self-made "False Belief Scale" constructed and standardized by the researcher has been used for the study for collecting student's opinion on false beliefs. An "Unstructured Interview Scheduled" has been used to know the parent's opinion regarding false beliefs.

The result of the study is not satisfactory. Lots of false beliefs exist among the students and their parents which demand necessary improvement through more in-depth study in future.
\end{abstract}

Key Words: False Beliefs, Students and Parents.

\section{INTRODUCTION}

India is the home to a number of superstitions. Certain hours and days are considered inauspicious. People consult astrologers and priests to know the auspicious hours, and days to start their work, projects and journey. Likewise, the time and date of marriage, inauguration, foundation-laying ceremonies are fixed according to the advice of astrologers and the position of the planets and stars. A cat crossing one' oath, the sight of a Brahmin, a sneeze or when someone interrupts or calls while one is going out are all considered to be bad sings. The hooting of an owl and the howling of a dog are considered to be signs of death and danger. Contracting chickenpox is considered to be the anger of a goddess. So, the goddess is appeased with offerings. When people build a new house or if it is a beautiful house, they hang an earthen pot with an ugly face painted on it on the facade of their house. Owners of new vehicles hang women's braids at the back of their vehicles to wards off evil eyes. Superstitions are typically seen as inconsequential creation of irrational minds. Nevertheless, many people rely on superstitious thoughts and practices in their daily routines in order to gain good luck. To date, little is known about the consequences and potential benefits of such consequences (Damisch et. al. 2010) People believe that luck factor has a great significance in life. Lucky events exert a dramatic influence over lives. Luck has the power to transform the improbable life and death, reward and ruin, happiness and disappear, many of these believes and behaviors are still with us (Wiseman, 2003). Superstitions can sometimes lead to horrifying crimes. Women, who were suspected of practicing witchcraft were tied and burnt alive. Joan of Arc was burnt to death because she was regarded by the English men as a witch. Child sacrifices are made to please gods.

\section{SIGNIFICANCE OF THE STUDY:}

The modern age is the age of science and technology. It helps us in transforming our lives in a faster way. For adjusting with the modern society, a person should have scientific thinking. Superstition has its own place in every nation and ethnicity. Even today, that we can predict most of events and happenings, and look into them from a scientific point of view, there are still some people who believe in the superstitious believes remaining from their ancestors and transfer these believes using the process of cultural acceptance and socialization to their children. For this purpose, the true understanding of this issue can be very useful for the process of socialization (Safaei and Khodabakhshi, 2012). Many people have the nature to stick to their own ideas and beliefs which they feel is correct. If we notice our Indian Society, many people are still suffering from false beliefs. India with a tradition of skepticism and a heavy baggage of superstitions and religious dogmatism demand scientific temper (Chowdhury, 2013).Lots of instances can be mentioned in this direction. For example, seeing an elephant (popularly known as Ganesha) is considered lucky. Consulting the astrologer for fixing an 
auspicious time for marriage, for changing and buying new houses, crossing a cat when we are walking or driving may cause accidents, blinking left eye is a sign of danger and many more. Moreover, the mind of the people of Assam is also not free from some false beliefs. A large number of witch hunting cases were reported from different parts of Assam during the last few years. A number of false beliefs such as eating food at the time of solar eclipse is harmful, a number of diseases are caused by witches, rhino's horn have many medicinal values, etc. are also very much prevalent in this region. There have been at least 65 cases of witch hunting reported during 2007-2012 from Assam alone. The practice is more prominent among the Rabha, Hajong, Mishing, Bodo and the Adivasi community in Assam. Many researchers did researches on false beliefs. Significant quantitative differences and a few qualitative differences were found in the incidence of false beliefs between the white and coloured children studying in secondary grades (Keurst, 1939). Girls expressed belief in a greater number of superstitions than boys ((Maller and Lundeen, 1933). The girls did slightly better than the boys on the superstitious test (Ebert, 1946). A large number of superstitious behavior was found among professional baseball players (Burger and Lynn, 2005). Women are more superstitious than men (Torgler, 2003). There is a mean difference between male and female false beliefs (Ebrahimizad, 2014). There is an existence of superstition and belief in human behavior (Beck and Forstmeier, 2005). It was found that those who hold positive attitude towards witchcraft have higher intension to pay a visit a witchcraft themed destination (Zhang, 2012). All these points indicated the importance of studying false beliefs existing in society. So, the researcher has decided to study the false beliefs of students of scheduled caste community of Dibrugarh town of Assam and their parents.

\section{OBJECTIVES OF THE STUDY:}

The major objectives of the study are:

3.1.1 To compare the false beliefs of boys and girls of SC community studying in higher educational institutions of Dibrugarh town.

3.1.2 To compare the false beliefs of urban and rural students of SC community studying in higher educational institutions of Dibrugarh town.

3.1.3 To compare the false beliefs of students of SC community studying in higher educational institutions with different medium of instruction, i.e. (a) English (b) Bengali and (c) Assamese.

3.1.4 To study the false beliefs existing among the parents of the students of SC community studying in higher educational institutions of Dibrugarh town.

IV.

HYPOTHESES OF THE STUDY:

The major hypotheses of the study are:

4.1.1 There is no significant difference between boys and girls of SC community studying in higher educational institutions of Dibrugarh town as far as their false beliefs is concerned.

4.1.2 There is no significant difference between urban and rural students of SC community studying in higher educational institutions of Dibrugarh town as far as their superstitious belief is concerned.

4.1.3 There is no significant difference between students studying in higher educational institutions of Dibrugarh town of SC community with different medium of instruction, viz, (a) English, (b) Bengali and (c) Assamese as far as their superstitious belief is concerned.

\section{METHODS AND PROCEDURES:}

5.1.1 Methods Used: The nature of the data collected in order to test the hypotheses demand normative survey method. Hence, Normative Survey method is used in the present study.

5.1.2 Sample: This study is based on primary data collection. Total 4 institutions namely Monohari Devi Kanoi Girls College, Dibru College, City College and Victoria School (having Higher Secondary Classes) were selected for the present study. From these selected institutions, total 120 scheduled caste students of Arts Stream and their parents were selected by using incidental sampling technique.

The following table shows the distribution of these selected 120 sample students under the following three

categories -

\begin{tabular}{|l|l|l|}
\hline Gender & Area of Settlement & Medium of Instruction \\
\hline Girls -49 & Urban -77 & Bengali Medium Students - 22 \\
\hline Boys -71 & Rural -43 & English Medium Students - 39 \\
\hline & & Assamese Medium Students - 59 \\
\hline Total -120 & Total -120 & Total - 120 \\
\hline
\end{tabular}




\section{TOOLS USED IN THE PRESENT STUDY:}

6.1.1 Unstructured Interview Schedule: An unstructured interview schedule constructed by the researcher was used in the present study for collecting necessary data on false beliefs from the students as well as the parents of the students studying in higher educational institutions of Dibrugarh town.

VII.

COLLECTION OF DATA:

The researcher herself administered the scale among the students when the institutions were open in sessions. The researcher visited the institutions and distributed the superstitious belief scale and collected the required data.

\section{ANALYSIS OF DATA:}

In order to compare the false beliefs of students studying in higher educational institutions of Dibrugarh town, ' $t$ ' test was used. The following tables show gender wise, medium wise comparison of students of SC community studying in higher educational institutions with respect to their false beliefs.

Table- 1Caste Wise Comparison between Boys and Girls with respect to their False beliefs

\begin{tabular}{|c|c|c|c|c|c|c|c|}
\hline Categories & $\mathbf{N}$ & Dimensions & Mean & SD & t & Df & Significance \\
\hline Girls & 49 & $\begin{array}{c}\text { Aversion to } \\
\text { Superstitions }\end{array}$ & 22.56 & 12.98 & 4.87 & 118 & $\begin{array}{c}\text { Significant at } .01 \\
\text { level }\end{array}$ \\
\hline Boys & 71 & $\begin{array}{c}\text { Aversion to } \\
\text { Superstitions }\end{array}$ & 13.13 & 11.65 & & \\
\hline
\end{tabular}

The following null hypothesis was formulated for testing if there is any significant difference between girls and boys studying in higher educational institutions with respect to the dimension 'Aversion to Superstitions', the null hypothesis was formulated as; "There is no significant difference between girls and boys studying in higher educational institutions of Dibrugarh town with respect to the dimension aversion to superstitions". The ' $t$ ' value is found to be 4.87 which is significant at .01 level. Hence, the null hypotheses could be rejected at .01 level of significance (Table value=2.58). Thus, there is a significant difference between girls and boys of SC community studying in higher educational institutions of Dibrugarh town with respect to the dimension 'Aversion to Superstitions'.

Table- 2

Caste Wise Comparison between Urban and Rural Students with respect to their False Beliefs

\begin{tabular}{|c|c|c|c|c|c|c|c|}
\hline Categories & N & Dimension & Mean & SD & t & Df & Significance \\
\hline Urban & 77 & Aversion to Superstitions & 22.29 & 23.45 & 21.44 & 118 & Significant at .01 level \\
\hline Rural & 43 & Aversion to Superstitions & 16.98 & 9.56 & & & \\
\hline
\end{tabular}

To test if there is any significant difference between urban and rural students studying in higher educational institutions with respect to the dimension 'Aversion to Superstitions', the null hypotheses was formulated as"There is no significant difference between urban and rural students studying in higher educational institutions of Dibrugarh town with respect to the dimension aversion to superstitions". The ' $t$ ' value is found to be 21.44 which is highly significant at .01 level. Hence, the null hypothesis could be rejected at .01 level of significance (Table value=2.58). Thus, there is a significant difference between urban and rural students studying in higher educational institutions of Dibrugarh town with respect to the dimension'Aversion to Superstitions'

Table- 3

Medium Wise Comparison of Scheduled Caste Students with Respect to their False Beliefs

\begin{tabular}{|c|c|c|c|c|c|c|c|}
\hline Categories & $\mathbf{N}$ & Dimension & $\begin{array}{c}\text { Mea } \\
\mathbf{n}\end{array}$ & SD & $\mathbf{t}$ & Df & Significance \\
\hline $\begin{array}{l}\text { Bengali Medium } \\
\text { Students }\end{array}$ & 22 & $\begin{array}{c}\text { Aversion to } \\
\text { Superstitions }\end{array}$ & 33.55 & 12.43 & \multirow{2}{*}{4.56} & \multirow{2}{*}{118} & \multirow{2}{*}{ Significant at .01 Level } \\
\hline $\begin{array}{c}\text { English Medium } \\
\text { Students }\end{array}$ & 39 & $\begin{array}{c}\text { Aversion to } \\
\text { Superstitions }\end{array}$ & 42.45 & 19.45 & & & \\
\hline English Medium Students & 39 & $\begin{array}{c}\text { Aversion to } \\
\text { Superstitions }\end{array}$ & 22.56 & 13.34 & \multirow{2}{*}{7.33} & \multirow{2}{*}{118} & \multirow{2}{*}{ Significant at .01 Level } \\
\hline $\begin{array}{l}\text { Assamese Medium } \\
\text { Students }\end{array}$ & 59 & $\begin{array}{l}\text { Aversion to } \\
\text { Superstitions }\end{array}$ & 36.87 & 17.36 & & & \\
\hline Bengali Medium Students & 22 & $\begin{array}{l}\text { Aversion to } \\
\text { Superstitions }\end{array}$ & 35.87 & 14.56 & \multirow{2}{*}{1.32} & \multirow{2}{*}{118} & \multirow{2}{*}{ Significant at .05 Level } \\
\hline $\begin{array}{l}\text { Assamese Medium } \\
\text { Students }\end{array}$ & 59 & $\begin{array}{l}\text { Aversion to } \\
\text { Superstitions }\end{array}$ & 32.13 & 13.45 & & & \\
\hline
\end{tabular}

To examine if there is any significant difference of students studying in Bengali and English medium institutions with respect to the dimension 'Aversion to Superstitions', the null hypothesis was formulated as 
"There is no significant difference of students studying in Bengali and English medium institutions with respect to the dimension aversion to superstitions". Here, ' $t$ ' value is found to be 4.56 which is significant at .01 level. Hence, the null hypothesis could be rejected at .01 level of significance (Table value $=2.59$ ). Thus, there is a significant difference of students studying in Bengali and English medium institutions with respect to the dimension 'Aversion to Superstitions'.

To test if there is any significant difference of students studying in English and Assamese medium institutions with respect to the dimension 'Aversion to Superstitions', the null hypothesis was formulated as "There is no significant difference of students studying in English and Assamese medium institutions with respect to the dimension aversion to superstitions". Here, ' $t$ ' value is found to 7.33 which is significant at .01 level. Hence, the null hypothesis could be rejected at .01 level of significance (Table value $=2.59$ ). Thus, there is a significant difference ofstudents studying in English and Assamese medium institutions with respect to the dimension 'Aversion to Superstitions'.

The following null hypothesis was formulated for testing if there is any significant difference of students studying in Bengali and Assamese medium institutions with respect to the dimension 'Aversion to Superstitions', the null hypothesis was formulated as "There is no significant difference of students studying in Bengali and Assamese medium institutions with respect to the dimension aversion to superstitions. Here, ' $t$ ' value is found to be 1.32 which is not significant at .05 level. Hence, the null hypothesis could be accepted at .05 level of significance (Table value= 1.97). Thus, there is no significant difference between scheduled caste students studying in Bengali and Assamese medium institutions with respect to the dimension 'Aversion to Superstitions'.

\section{FALSE BELIEFS EXISTING AMONG THE PARENTS OF THE SCHEDULED CASTE STUDENTS STUDYING IN HIGHER EDUCATIONAL INSTITUTIONS OF DIBRUGARH TOWN:}

Data were collected from the parents of the students using an unstructured interview scheduled. On the basis of the analysis of the responses of the parents, the following superstitious beliefs were categorized, which were very much prevalent among the parents.

$>$ Almost all the parents believe that the chicken pox is a product of divine anger. They do not like to be treated by the doctors for chicken pox instead of worshipping goddess Shitla for a cure. The pox goddess is called 'Shitla' by the respondents of Bengali community. Chicken pox is a dread disease. They also believe some divine power worked behind Chicken pox. Usually medicine is not used by the respondents during chicken pox. Purity in body and mind (Sudhoo), cleanliness everywhere, worshipping goddess 'Shitla', Using 'Neem Pata' during bath are the precautions taken by them during chicken pox.

Some of the respondents believe in the existence of spirit. They believe in the existence of soul (Ghost). They believe in immortality of the soul of the dead person. They believe that the ghost is made free after the death of a man. With regard to human soul, replied that after death, human soul does not go away too far from the dead man's home until and unless the soul is prayed to leave the family for good by performing the ritual called 'Shraddha Ceremony'.

They believe in celebrating various traditional practices of celebrating various pujas. (Worshipping God) during different occasions for curing diseases is common among the respondents. Most of the respondents replied thatthey take active part in worshipping 'Manasha' the goddess of snake with a view to preventing snake bites and to be blessed by material wealth, children and worldly gains. They select Brahmin people for celebrating their religious festivals. Brahmins are mainly requestedto perform the religious ceremonies because it is believed by these respondents that the Brahmins have some sort of connections with God. They are known as 'Pujaris'.

$>$ Most of the respondents replied that marital relationship with people outside their own religion is not acceptable, it may cause physical harm. They also believe that miscarriages are ascribed to improper ceremonies performed during the marriage. They believe that the marriage ceremony are generally based on 'Gotra' exogamy. Cross-cousin marriage are not permitted and if so, it is considered as great sin.

$>$ It was believed that the girls are strictly prohibited to do some activities in the society. They believe that girl in their puberty period should strictly be isolated from certain family affairs. They also believe that as the women are polluted by menstruation, so during the period of such event, they should be debarred from participation in religious functions. 
Most of the respondents believe that at the time of solar eclipse, it is harmful to take meal or roaming outside. Solar eclipse can be a danger to pregnant women and their unborn child. The pregnant women should stay indoor during solar eclipse. They also believe that immediate after birth, the baby is not to be taken out of the house for twenty one days strictly and no outsider is allowed in the house during these days. The mother and the child should be kept separately from the other members of the family because they are regarded as polluted during this period. Most of the respondents are in the view that after the completion of these days, the child's horoscope need to be prepared.

\section{MAJOR FINDINGS OF THE STUDY:}

The major findings of the study are:

$>$ A significant difference was observed between girls and boys of scheduled caste community studying in higher educational institutions as far as their superstitious belief is concerned.

$>$ There was a significant difference between urban and rural students of scheduled caste community studying in higher educational institutions as far as their superstitious belief is concerned.

$>$ The present study observed a significant difference between scheduled caste students studying in Bengali and English medium institutions and English and Assamese medium institutions as far as their superstitious belief is concerned. However, no significant difference was observed between the scheduled caste students studying in Bengali and Assamese medium institutions as far as their false belief is concerned.

$>$ It was observed that false beliefs still exit among the parents of the students studying in higher educational institutions of Dibrugarh town.

\section{CONCLUSION:}

The present study revealed a significant difference between girls and boys and urban and rural students studying in higher educational institutions of Dibrugarh town. Medium wise differences were also observed between students of Dibrugarh town with respect to their superstitious belief. The present study also reported that false beliefs still exist among the parents of the students studying in higher educational institutions of Dibrugarh town.

\section{REFERENCES:}

[1] Beck, Jan and Forstmeier Wolfgang. (2005). Superstition and Belief as Inevitable by Products of an Adaptive learning Strategy. Human Nature, Spring. Vol-18, No-1, pp-35-46.

[2] Burger, Jerry M. and Lynn, Amy L. (2005) Superstitious Behaviour among American and Japanese Professional Baseball Players. Basic and Applied Social Psychology. Vol-27, No-1, pp-71-76.

[3] Chowdhury, K.K. (2013). Science Centres Promoting Scientific Temper, Science and Culture , http://www.scienceandculture-isna.org/nov-dec-13/o20ccr1g/target.html. Retrieved On: 2-12-2014.

[4] Damisch, Lysann., Stoberock Barbara and Mussweiler, Thomas. (2010). Keep Your Finger Crossed. How Superstition Improves Performance. Psychological Science, APS (Association for Psychological Science), Vol-21, No-7, pp-1014-1020. http://pss.sagepub.com Retrieved on: 15-9-12.

[5] Ebert, Stephen Joseph. (1946). An Experimental Investigation of the Relationship between False beliefs and Emotional Mal-Adjustment. Thesis, University of Southern California.

[6] Ebrahimizad, Roghyyeh (2014). False beliefs and Some of its Causes (Case Study: Ghachsaran Citizens). Bulletin of Environment, Pharmacology and Life Sciences. Academy for Environmental and Life Sciences, India. http://www.bepls.com Retrieved on: 11-2-2015.

[7] Keurst, Arthur J. Ter. (1939) The Acceptance of False beliefs among Secondary School Pupils. The Journal of Educational Research. Taylor and Francis Ltd.Vol-32, No-9, pp-673-685. http://www.jstor.org/stable/27526608 . Retrieved On: 15-09-12.

[8] Maller, Julius B., and Lundeen, Gerhard E. (1933). Sources of False beliefs. The Journal of Educational Research. Tylor and Francis Ltd, Vol-26, No-5, pp-321-343. http://www.jstor.org/stable/27525637 . Retrieved On: 15-9-2012.

[9] Safaei, Safiollah and Khodabakhshi, Akbar. (2012). A Study of Sociological Factors of Superstitions. Universal Journal of Education and General Studies, Transnational research Journal. Vol-1, No-8, pp-242-252. www.universalresearchjournals.org/ujegs Retrieved On: 12-3-2013.

[10] Torgler, Benno. (2003). It is About Believing, Superstition and Religiosity. CREAMA, Centre for Research in Economics, Management and the Arts. Working Paper No- 2003-10. www.creama_research.ch

[11] Wiseman, Richard (2003). The Luck Factor. Skeptical Inquirer, The Committee for the Scientific Investigation of Claims of the paranormal, pp-1-5.

[12] Zechender, Ashley. (2009). A Proposed Study of the Relationship between Professional Athletics Superstitious Behaviour and Athletic Performance. A Critical Dissertation, The California School of Professional Psychology, San Francisco bay Campus, Alliant International University.

[13] Zhang, Yunzhou (2012). The Effects of Superstitions as Destination, Attractiveness on Behavioural Intension. Thesis, Faculty of the Virginia Polytechnic Institute and State University. 